\title{
Somatic cell nuclear transfer in horses: effect of oocyte morphology, embryo reconstruction method and donor cell type
}

\author{
Irina Lagutina ${ }^{1}$, Giovanna Lazzari ${ }^{1}$, Roberto Duchi ${ }^{1}$, Silvia Colleoni ${ }^{1}$, Nunzia Ponderato ${ }^{1}$, \\ Paola Turini ${ }^{1}$, Gabriella Crotti ${ }^{1}$ and Cesare Galli ${ }^{1,2}$ \\ ${ }^{1}$ Laboratorio di Tecnologie della Riproduzione, Istituto Sperimentale Italiano Lazzaro Spallanzani, CIZ srl, \\ via Porcellasco 7/f, 26100 Cremona, Italy and ${ }^{2}$ Dipartimento Clinico Veterinario, Università di Bologna, \\ via Tolara di Sopra, 50-40064 Ozzano Emilia (Bologna), Italy
}

Correspondence should be addressed to C Galli, Laboratorio di Tecnologie della Riproduzione, Istituto Spermentale Italiano Lazzaro Spallanzani, CIZ srl, via Porcellasco 7/f, 26100 Cremona, Italy; Email: cesaregalli@Itr.191.it

\begin{abstract}
The objective of the present work was to investigate and clarify the factors affecting the efficiency of somatic cell nuclear transfer (NT) in the horse, including embryo reconstruction, in vitro culture to the blastocyst stage, embryo transfer, pregnancy monitoring and production of offspring. Matured oocytes, with zona pellucida or after zona removal, were fused to cumulus cells, granulosa cells, and fetal and adult fibroblasts, and fused couplets were cultured in vitro. Blastocyst development to Day 8 varied significantly among donor cells (from $1.3 \%$ to $16 \%, P<0.05$ ). In total, 137 nuclear transfer-embryos were transferred nonsurgically to 58 recipient mares. Pregnancy rate after transfer of NT-embryos derived from adult fibroblasts from three donor animals was $24.3 \%$ (9/37 mares transferred corresponding to 9/101 blastocysts transferred), while only $1 / 18(5.6 \%)$ of NT-blastocysts derived from one fetal cell line gave rise to a pregnancy (corresponding to $1 / 33$ blastocysts transferred). Overall, seven pregnancies were confirmed at 35 days, and two went to term delivering two live foals. One foal died $40 \mathrm{~h}$ after birth of acute septicemia while the other foal was healthy and is currently 2 months old.

These results indicate that (a) the zona-free method allows high fusion rate and optimal use of equine oocytes, (b) different donor cell cultures have different abilities to support blastocyst development, (c) blastocyst formation rate does not correlate with pregnancy fate and (d) healthy offspring can be obtained by somatic cell nuclear transfer in the horse.

Reproduction (2005) 130 559-567
\end{abstract}

\section{Introduction}

Somatic cell nuclear transfer has been the subject of much investigation in the last few years and, as a result, several mammalian species have been cloned (see Galli et al. 2003 a for review). In Equids, the birth of three mule foals cloned from fetal cells (Woods et al. 2003) and one horse foal cloned from adult somatic cells (Galli et al. 2003 b) has only recently been reported. Remarkably, all foals were born alive and survived to adulthood.

This relatively late and limited application of somatic cell nuclear transfer is a consequence of the limited information available in the literature on assisted reproductive techniques in Equids, in particular oocyte maturation and in vitro culture of early pre-implantation embryos. Indeed, the work that led to the cloning of mules (Wood et al. 2003) relied on in vivo matured oocytes that were transferred to the oviducts of recipient mares immediately after nuclear transfer and activation. Only the work of Galli et al. (2003b) has been carried out completely in vitro up to the blastocyst stage.

One reason for the limited development of assisted reproduction techniques in Equids is the limited interest demonstrated by the horse industry, contrary to the cattle industry that still plays a very active role in the development and application of reproductive biotechnologies in ruminants. In general, few studies are available in the literature on equine in vitro embryo production (see reviews by Squires et al. 2003, Westhusin et al. 2003), and it is only recently that reports have been published on completely in vitro production of equine preimplantation embryos by means of in vitro oocyte maturation, fertilization by intracytoplasmic sperm injection (ICSI) and in vitro culture (Galli et al. 2002a, Lazzari et al. 2002a, Choi et al. 2004). These latter reports demonstrate the real possibility of applying a completely in vitro procedure for obtaining 
horse ICSI blastocysts able to establish a pregnancy (Galli et al. 2001a, 2002b) and develop to live term offspring (present authors, unpublished data).

In horse nuclear transfer, the availability of horse oocytes is a limiting factor due to the anatomy and physiology of the mare's ovary which makes this species a poor oocyte donor as compared with other large domestic species. Oocytes can be harvested from the ovaries of slaughtered mares (Zhang et al. 1989) or from ovum pick up (OPU) of live donors. On average it is possible to recover 3-4 immature oocytes per ovary from the ovaries of slaughtered animals (Galli \& Lazzari 2001, Lazzari et al. 2002a); oocyte retrieval from live donors by OPU is slightly more variable and can be from 3 to 6 oocytes per session of OPU (Galli et al. 2002a, Lorenzo et al. 2002). The maturation rate of horse oocytes is also quite variable, averaging between 25 and $70 \%$ in published studies (Hinrichs \& Williams 1997, Carneiro et al. 2001, Dell'Aquila et al. 2001, 2003, Bogh et al. 2002, Choi et al. 2002, Lorenzo et al. 2002). Interestingly, in the horse the recovered cumulus-oocyte complexes are a mixed population with either a compact or an expanded cumulus. While expanded cumulus-oocyte complexes are often discarded for in vitro embryo production in cattle and pigs, they represent about $40 \%$ (2060/5127, our observations) of the total population of recovered oocytes in the horse and seem to have some developmental competence for maturation (Dell'Aquila et al. 2003), cleavage (Choi et al. 2002) and blastocyst formation (Zhang et al. 1989). Another peculiar aspect specifically relevant to horse nuclear transfer is the reported (Choi et al. 2002, Li et al. 2002) low ability of oocytes to fuse with donor cells and the limited developmental competence of nuclear transfer (NT)embryos in vitro. Even high DC voltage pulses of $2.2-2.5 \mathrm{kV} / \mathrm{cm}$ were able to fuse less than $60 \%$ of couplets, the cleavage rate was $35-50 \%$ and only about $2.5 \%$ of NTembryos reached the blastocyst stage (Li et al. 2002).

The refinement of the in vitro culture conditions suitable for equine oocyte maturation and embryo development (Galli et al. 2002a, Lazzari et al. 2002a), the development of an adequate horse oocyte activation protocol (Lazzari et al. 2002b) and the application of zona-free manipulation for embryo reconstruction (Booth et al. 2001, Oback et al. 2003, Vajta et al. 2003), are all fundamental steps for the development of a successful in vitro procedure for somatic cell nuclear transfer in the horse. In this paper we describe, in detail, all the technical aspects involved in the in vitro production of cloned blastocysts in the horse. The objectives of our research concentrated on the optimization of the nuclear transfer procedure to make efficient use of the limited number of oocytes available in this species. Both expanded and compact cumulusoocyte complexes were used as well as a modified zonafree method for embryo reconstruction that is known to increase the fusion rate in other species (Oback et al. 2003). Different sources of donor somatic cells were compared in various experiments for their ability to develop to the blastocyst stage and to term.

\section{Materials and Methods}

Unless otherwise indicated, chemicals were purchased from Sigma-Aldrich (Milan, Italy), and plastic-ware was from Nunc (Roskilde, Denmark).

\section{Oocyte collection and in vitro maturation}

Ovaries of slaughtered mares of mixed breeds were collected during the breeding season at $45^{\circ}$ latitude (Italy, northern hemisphere). Cumulus-oocyte complexes (COCs) were recovered by a combination of scraping and washing of the inner wall of follicles that were between 0.5 and $3.0 \mathrm{~cm}$ in diameter with a Jacobson curette and a syringe filled with PBS. The fluid was recovered into Petri dishes containing Hepes-buffered TCM 199 supplemented with $1 \mathrm{mg} / \mathrm{ml}$ BSA and $10 \mu \mathrm{g} / \mathrm{ml}$ heparin. COCs were classified as either compact or expanded depending on cumulus and granulosa cell morphology (Fig. 1a,b), and transferred separately to maturation medium (Galli et al. $2001 a, 2002 a, 2002 b)$. Briefly, the maturation medium was TCM 199 supplemented with 10\% fetal calf serum (FCS), $1 \mu \mathrm{l} / \mathrm{ml}$ insulin, transferin, sodium selenite (ITS), $1 \mathrm{mM}$ sodium pyruvate, $50 \mathrm{ng} / \mathrm{ml}$ long-epidermal growth factor, $100 \mathrm{ng} / \mathrm{ml}$ long-insulin-like growth factor-I and $0.1 \mathrm{IU} / \mathrm{ml}$ each of follicle-stimulating hormone and luteinizing hormone (Pergovet, Serono, Italy). COCs were matured for $22-24 \mathrm{~h}$ in 4 -well plates at $38.5^{\circ} \mathrm{C}$ in an atmosphere of $5 \%$ $\mathrm{CO}_{2}$ in air.

\section{Preparation of nuclear donor cells}

Cumulus cells from COCs of mixed breeds after $22-24 \mathrm{~h}$ of maturation were collected after removal of the cumulus from oocytes in synthetic oviductal fluid-Hepes (SOF-Hepes) with hyaluronidase $(1 \mu \mathrm{g} / \mathrm{ml})$, trypsinized $(2.5 \mathrm{mg} / \mathrm{ml})$, pelleted by centrifugation at $200 \mathrm{~g}$ for $5 \mathrm{~min}$, resuspended in SOF-Hepes and used for nuclear transfer within $2-3 \mathrm{~h}$. Granulosa cells were collected during ovum pick up from a Haflinger mare (Galli et al. 2001b, 2002b), purified from blood cells on a Percoll gradient $45 \%$ in TCM 199), plated in $60 \mathrm{~mm}$ tissue culture dishes and cultured in DMEM with $10 \%$ FCS in $5 \% \mathrm{CO}_{2}$ and $5 \% \mathrm{O}_{2}$ in humidified air at $38.5^{\circ} \mathrm{C}$. After expansion of cells in culture they were either subcultured every 4 days or frozen in $10 \%$ DMSO and stored in liquid nitrogen.

Adult fibroblasts were produced by organ culture of minced tissue from chest biopsies of adult animals of the Haflinger and Arabian breeds. Fetal fibroblasts were produced as described for adult fibroblasts from an aborted 6-month-old fetus cloned from an adult fibroblast cell line. Both adult and fetal fibroblasts were cultured and stored as described for granulosa cells. Cells were used at passage number 5 to 15 . 
Before using the cells in NT experiments, granulosa cells and fibroblasts were induced into quiescence by either serum starvation $(0.5 \%$ FCS ) for $1-3$ days or by growth to confluence. A cell suspension was prepared by trypsinization of cell culture $30 \mathrm{~min}$ before nuclear transfer, washed and resuspended in SOF-Hepes.

\section{Preparation of enucleated oocytes (cytoplasts) and NT-embryo construction}

After 22-24h of maturation the oocytes were denuded of cumulus cells by pipetting first in the presence of hyaluronidase, then placed in $0.25 \%$ trypsin for $1.5 \mathrm{~min}$ and afterwards in SOF-Hepes with 10\% FCS where the cumulus cells were completely removed by pipetting. Finally, the oocytes were returned to maturation medium. For reconstruction of NT-embryos we used both the zonaenclosed and zona-free methods (Oback et al. 2003). For the zona-enclosed method, oocytes with an extruded polar body were stained with Hoechst 33342 in the presence of cytochalasin B $(5 \mu \mathrm{g} / \mathrm{ml})$. Enucleation was performed by the aspiration of the polar body and metaphase II plate in a minimal volume of ooplasm under UV light. All manipulations were in SOF-Hepes with $6 \mathrm{mg} / \mathrm{ml}$ BSA (Gardner et al. 1994), except fusion. Individual nuclear donor cells prepared as described above (cumulus cells $22-24 \mathrm{~h}$ of maturation or adult fibroblasts) were transferred into the perivitelline space of zonaenclosed cytoplasts with the enucleation pipette. The cytoplast-karyoplast couplets were transferred in $0.3 \mathrm{M}$ mannitol $(50 \mu \mathrm{MCa}$ and $100 \mu \mathrm{MMg})$ solution and fused one or two times within a 15 to $30 \mathrm{~min}$ interval by a double DC pulse of $1.8-2.4 \mathrm{kV} / \mathrm{cm}$ applied for $30 \mu \mathrm{s}$ at $26-27 \mathrm{~h}$ of maturation. For the zona-free method, the zona pellucida of oocytes with extruded polar bodies was digested with $0.5 \%$ pronase in PBS. Zona-free oocytes were enucleated under UV light with a blunt micropipette (with perpendicular break). All manipulations were performed in SOF-Hepes with 10\% FCS. Subsequently, zonafree cytoplasts were individually washed for a few seconds in $300 \mu \mathrm{g} / \mathrm{ml}$ phytohemagglutinin $\mathrm{P}$ in TCM 199-Hepes and then quickly dropped over a single donor cell (Vajta et al. 2003) settled to the bottom of a drop of TCM 199 with $0.5 \%$ FCS. Formed cell couplets were washed in $0.3 \mathrm{M}$ mannitol $(50 \mu \mathrm{MCa}$ and $100 \mu \mathrm{MMg})$ solution and fused one or two times at 15 to $30 \mathrm{~min}$ intervals by a single DC pulse of $1.2 \mathrm{kV} / \mathrm{cm}$ applied for $30 \mu \mathrm{s}$ at $26-27 \mathrm{~h}$ of maturation.

\section{Activation}

Oocytes and NT-embryos were activated $1-2 \mathrm{~h}$ after fusion at $27-28 \mathrm{~h}$ of maturation. Oocytes and NT-embryos were treated with $8.7 \mu \mathrm{M}$ ionomycin in SOF-Hepes for $4 \mathrm{~min}$ followed by $4 \mathrm{~h}$ culture in a combination of $1 \mathrm{mM}$ 6-(dimethylamino) purine (6-DMAP) and $5 \mu \mathrm{g} / \mathrm{ml}$ cycloheximide in SOF supplemented with MEM essential and non essential amino acids, $1 \mathrm{mM}$ glutamine, and $4 \mathrm{mg} / \mathrm{ml}$ BSA (m-SOFaa) (Lazzari et al. 2002b).

\section{Embryo culture}

Zona-enclosed and zona-free embryos were cultured, respectively, in $20 \mu \mathrm{l}$ culture drops and individually in $3 \mu \mathrm{l}$ drops of $\mathrm{m}$-SOFaa with $4 \mathrm{mg} / \mathrm{ml} \mathrm{BSA}$ in $5 \% \mathrm{CO}_{2}$ and $5 \% \mathrm{O}_{2}$ in humidified air at $38.5^{\circ} \mathrm{C}$ under mineral oil. Half of the medium was renewed on Day 3 with fresh m-SOFaa and on Day 5 with TCM 199 with 5\% FCS and 5\% Serum Replacement (Knockout SR, Gibco BRL) (Day 0 was the day of fusion and activation). Cleavage was assessed $48 \mathrm{~h}$ after activation, the rate of blastocyst formation was recorded at Day 7 and Day 8 when the embryos were either frozen or transferred to synchronized recipients (Fig. 1c,d).

\section{Embryo transfer and foaling}

Embryo transfer to recipients was performed over 3 breeding seasons (2002-2004). Haflinger mares were examined $2-3$ times a week by ultrasound to determine the day of ovulation. Three to seven days after ovulation the mares received one to four Day 7 or Day 8 blastocysts (fresh or after thawing) by nonsurgical transfer. On Day 17 after ovulation the animals were examined $(5 \mathrm{MHz}$ linear probe, Sonovet 600, Medison) for pregnancy diagnosis and thereafter were examined weekly throughout the first trimester of pregnancy and later at monthly intervals until foaling.

All the experiments that involved the use of recipient animals were carried out under veterinary supervision in accordance with Decreto Legislativo 116/92 that regulates the use of animal experimentation in Italy.

\section{Statistical analysis}

Differences between the experimental groups were verified using the Chi-square test or Student's $t$-test. $P<0.05$ was considered significant.

\section{Results}

\section{Comparison of two methods of NT-embryo reconstruction}

The development of NT-embryos reconstructed with either cumulus cells or adult fibroblasts by two different methods is summarized in Table 1. In this experiment only compact oocyte-cumulus complexes were used. The results indicate that more oocytes were fused and the cleavage rate was higher in the zona-free system $(P<0.05)$. The rate of blastocyst formation of the fused couplets was generally low $(1.3-2.9 \%$ for cumulus cells and $4.2-6.4 \%$ for fibroblasts on Day 8) and did not differ significantly between groups. However, when comparing the efficiency of the two systems by calculating the percentage of enucleated oocytes subjected to fusion that developed 

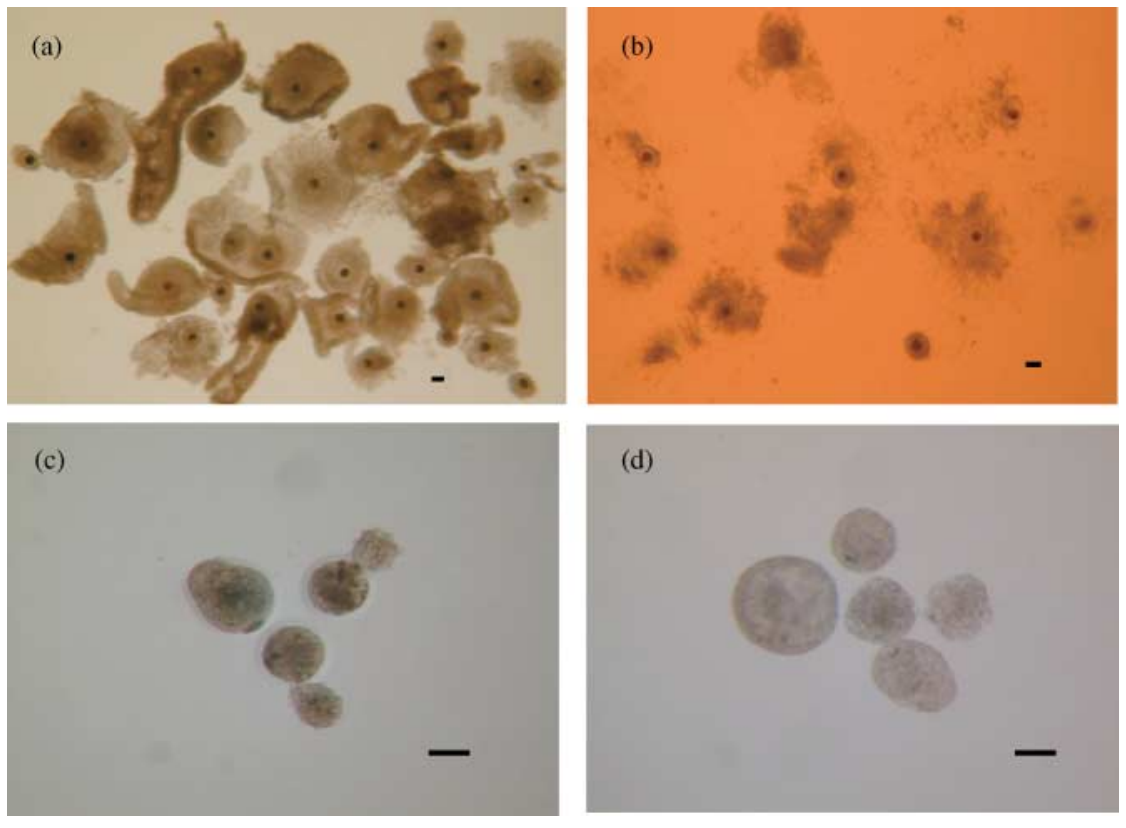

Figure 1 Equine cumulus-oocyte complexes of compact (a) and expanded (b) morphology before in vitro maturation. NT-horse blastocysts on Day 8 from zonaenclosed manipulation (c) and from zona free manipulation (d). Bars $=100 \mu \mathrm{m}$.

Table 1 Development of horse NT-embryos reconstructed by zona-enclosed versus zona-free methods. The number of replicates was $\geq 4$.

\begin{tabular}{|c|c|c|c|c|c|c|}
\hline \multirow[b]{2}{*}{ Donor cells } & \multirow[b]{2}{*}{ Method of NT } & \multirow{2}{*}{$\begin{array}{l}\text { No. of oocytes } \\
\text { enucleated }(\%)\end{array}$} & \multirow{2}{*}{$\begin{array}{l}\text { No. of couplets } \\
\text { fused }(\%)\end{array}$} & \multirow{2}{*}{$\begin{array}{c}\text { Cleaved } \\
(n(\% \text { of fused }))\end{array}$} & \multicolumn{2}{|c|}{ Blastocysts on Day 8} \\
\hline & & & & & $(n(\%$ of fused $))$ & (\% of oocytes) \\
\hline \multirow[t]{2}{*}{ Cumulus } & Zona-enclosed & 113 & $78(69)^{\mathrm{a}}$ & $54(69.2)^{C}$ & $1(1.3)$ & 0.9 \\
\hline & Zona-free & 104 & $104(100)^{b}$ & $88(84.6)^{d}$ & $3(2.9)$ & 2.9 \\
\hline \multirow[t]{2}{*}{ Adult fibroblasts } & Zona-enclosed & 181 & $120(66.3)^{\mathrm{a}}$ & $82(68.3)^{\mathrm{C}}$ & $5(4.2)$ & 2.7 \\
\hline & Zona-free & 193 & $187(97)^{b}$ & $159(85.0)^{d}$ & $12(6.4)$ & 6.2 \\
\hline
\end{tabular}

Values with different letters within columns differ significantly, $P<0.05$ (Chi-square).

into Day 8 blastocysts (Table 1, blastocysts on Day 8 , percent of oocytes), we found that the zona-free method is about 3.2 times more effective than the zona-enclosed method in the case of cumulus-derived NT-embryos and 2.3 times more effective in the case of fibroblast-derived NT-embryos.

\section{Development of NT-embryos derived from oocytes with expanded and compacted cumulus before maturation}

For this experiment we used adult fibroblasts from 3 different donor animals (female A, male B and male C) with a minimum of 3 replicates. Overall, 413 embryos from compacted and 197 from expanded cumulus-oocyte complexes were reconstructed and cultured in this experiment. The cleavage rate of NT-embryos derived from fibroblasts of male B was significantly higher in the compacted cumulus group (95.9\% vs $84.6 \%$ ), while no differences were observed for donors $A$ and $C$. However, the development to the blastocyst stage was not affected by the type of oocyte used (compacted versus expanded: B, $6.0 \%$ vs $8.3 \%$; A, $4.1 \%$ vs $4.6 \%$; C, $1.8 \%$ vs $1.9 \%$ ).

\section{Developmental competence of horse NT-embryos derived from different cell types}

We tested the developmental ability of NT-embryos derived from cultured granulosa cells, cumulus cells, and adult and fetal fibroblasts from various donor animals and in parallel with the developmental ability of parthenogenetically activated matured (MetlI) oocytes (Table 2). There was no difference in the rate of cleavage between parthenogenetic and NT-embryos derived from different donor cell types obtained by the zona-free method. The developmental capacity of NT-embryos to form blastocysts on Day 8 differed among donor cells (from 1.3\% to $16 \%$, $P<0.05)$. NT-embryos derived from adult fibroblasts of male $\mathrm{B}$ and from fetal fibroblasts (cloned fetus from male C) were better able to support development to blastocysts and this rate was similar to the rate of parthenogenetic development (Table 2).

\section{Embryo transfer, pregnancies and offspring (Table 3)}

In total, 137 blastocysts were transferred to 58 recipient mares. The average pregnancy rate per mare was $17.2 \%$ 
Table 2 Development of horse NT-embryos derived from different types of nuclear donor cells. The number of replicates was $\geq 4$.

\begin{tabular}{|c|c|c|c|c|c|}
\hline Donor of cells for NT & Cells & Method of NT & Number of embryos & Cleaved $^{*}(n(\%))$ & Blastocysts on Day $8(n(\%))$ \\
\hline Different females & Cumulus cells & ZE or ZF & 182 & $142(78.0)$ & $4(2.20)^{a, c}$ \\
\hline Female A & Granulosa cells & ZE or ZF & 67 & $49(73.1)$ & $0(0)^{\mathrm{a}}$ \\
\hline Female A & Adult fibroblasts & $\mathrm{ZE}$ or $\mathrm{ZF}$ & 139 & $111(79.9)$ & $7(5.0)^{\mathrm{a}, \mathrm{b}, \mathrm{c}}$ \\
\hline Male B & Adult fibroblasts & ZF & 120 & $113(94.2)$ & $19(15.8)^{\mathrm{d}}$ \\
\hline Male C & Adult fibroblasts & $\mathrm{ZF}$ & 616 & $560(90.9)$ & $8(1.3)^{c}$ \\
\hline Cloned fetus of male C & Fetal fibroblasts & ZF & 144 & $138(95.5)$ & $23(16)^{d}$ \\
\hline Parthenogenetic control & & & 91 & $80(87.9)$ & $12(13.2)^{b, d}$ \\
\hline
\end{tabular}

ZE, zona-enclosed; ZF, zona-free.

Values with different letters within columns differ significantly, $P<0.05$ (Chi-square).

*Statistics were not applied because the first three groups were manipulated with both ZE and ZF methods and the last four groups only with ZF method and therefore they were not directly comparable. No difference was observed within the first three and within the last four groups.

(10/58) on Day 17 and per blastocyst was 7.3\% (10/137). The pregnancy rate per mare/per blastocyst was $0 \% / 0 \%$, $5.6 \% / 3.0 \%$ and $24.3 / 8.9 \%$ for NT-embryos derived from cumulus cells, fetal fibroblasts and adult fibroblasts respectively. Six pregnancies from NT-embryos obtained from adult cells were confirmed at Day 35. The highest pregnancy rates were obtained in recipients when Day 7 and Day 8 NT-blastocysts were transferred on Day 4 or 5 of the cycle (data not shown). A single pregnancy derived from NT-embryos reconstructed with fetal fibroblasts (derived from a previously aborted fetus from male C, Galli et al. 2003b)) aborted at 180 days and one pregnancy from NT-embryos reconstructed from adult fibroblasts of male $\mathrm{C}$ was lost at 231 days of gestation. The two late abortions were both from the same genotype (male C), one from adult cells and one from fetal cells. Remarkably, both shared the same abnormality (see Fig. $2 b$ and d) on the umbilical cord with a cystic structure filled with allantoic fluid; this cyst was likely to be a dilatation of the uracus and was the only abnormality observed in otherwise normal fetuses and placentae at necroscopy. The placenta of the fetus originating from the fetal cells presented an area without villi (see Fig. 2a). The fetus was aborted at 180 days (Fig. 2c) and was apparently normal at necroscopy. Two pregnancies developed to term and delivered two live foals from the same male genotype (B). The first foal was delivered after 344 days of pregnancy; it weighed $49 \mathrm{~kg}$ while the placenta was $4.6 \mathrm{~kg}$. This foal was apparently normal, stood up on its own, and nursed within $2 \mathrm{~h}$ after birth. However, $24 \mathrm{~h}$ after birth he developed a mas- sive diarrhea that rapidly caused the death of the foal $40 \mathrm{~h}$ after birth. Laboratory analysis and anatomo-pathological examination confirmed that the foal developed a hemorrhagic enteritis that evolved into septicemia, while no other gross morphological abnormalities were reported at necroscopy. The second foal was delivered after 329 days of gestation; it weighed $42 \mathrm{~kg}$ and the placenta was $4.1 \mathrm{~kg}$. Like the previous foal, this one stood up on its own, nursed within $2 \mathrm{~h}$ after birth and developed well without any sort of problems (Fig. 3). At present he is 2 months old and growing very well.

\section{Discussion}

In our study we found that the use of the zona-free method for nuclear transfer embryo reconstruction significantly increased the fusion rate - up to nearly $100 \%$ after two rounds of cell fusion. Interestingly, this result was favorable compared with the combination of cell fusion and treatment with inactivated Sendai virus of zonaenclosed couplets (87\%; Li et al. 2002). This effect might be the result of both the cleaner cytoplasmic membrane that favored a closer contact between the oocyte and the somatic cell membrane as well as the reduced DC field required to achieve successful fusion $(1.8-2.4 \mathrm{kV} / \mathrm{cm}$ vs $1.2 \mathrm{kV} / \mathrm{cm})$. A high DC field also caused some couplets to lyze (our observations). This low-strength field is also a possible explanation why we did not find differences in the cleavage rate between parthenogenetic and nuclear transfer zona-free embryos. This was not the case for

Table 3 Embryo transfer and pregnancy

\begin{tabular}{|c|c|c|c|c|c|c|c|c|}
\hline Donor cells & Horse & No. of embryos & No. of recipients & $\begin{array}{l}\text { Pregnancy } \\
(n(\%))\end{array}$ & $\begin{array}{c}35 \text { days } \\
(n(\%))\end{array}$ & 3 months & 6 months & $\begin{array}{c}\text { Offspring } \\
(n(\%))\end{array}$ \\
\hline Cumulus 22 hIVM & * & 3 & 3 & $0(0)$ & $0(0)$ & $0(0)$ & $0(0)$ & $0(0)$ \\
\hline Fetal fibroblasts§ & C & 33 & 18 & $1(5.6)$ & $1(5.6)$ & $1(5.6)$ & $1(5.6)$ & $0(0)$ \\
\hline Adult fibroblasts & A & 4 & 2 & $1(50)$ & $0(0)$ & $0(0)$ & $0(0)$ & $0(0)$ \\
\hline Adult fibroblasts & B & 71 & 23 & $6(26.1)$ & $4(17.4)$ & $3(13)$ & $2(8.7)$ & $2(8.7)$ \\
\hline Adult fibroblasts & C & 26 & 12 & $2(16.7)$ & $2(16.7)$ & $1(8.3)$ & $1(8.3)$ & $0(0)$ \\
\hline Adult fibroblasts & Total & 101 & 37 & $9(24.3)$ & $6(16.2)$ & $4(10.8)$ & $3(8.1)$ & $2(5.4)$ \\
\hline
\end{tabular}

*cumulus cells of oocytes from slaughtered mares; § fetal fibroblasts derived from an aborted cloned fetus of male C.

Chi square, $\mathrm{P}<0.05$ statistical differences. 
(a)

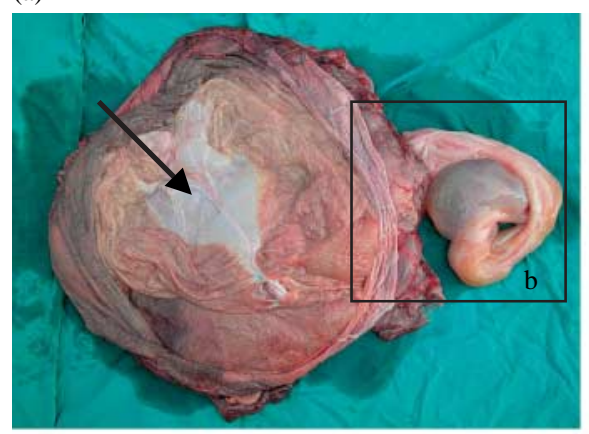

(c)

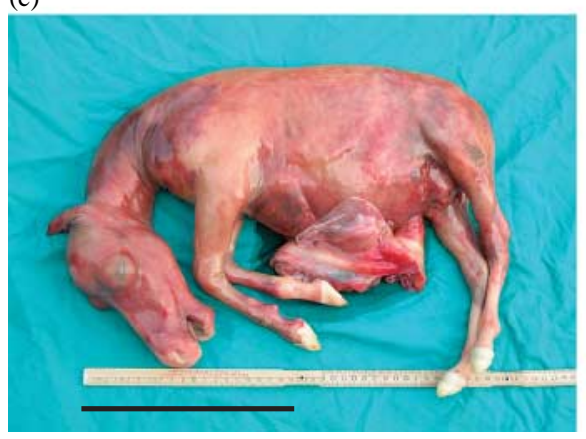

(b)

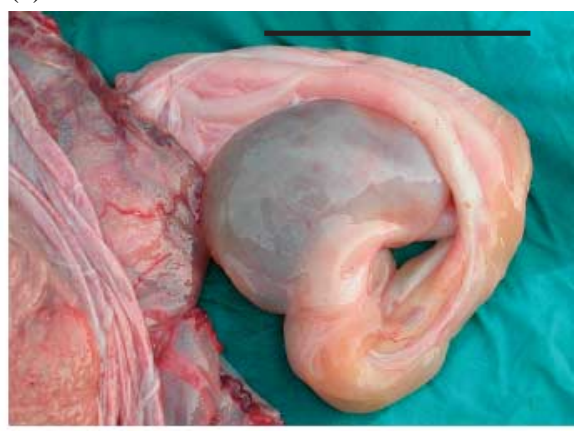

(d)

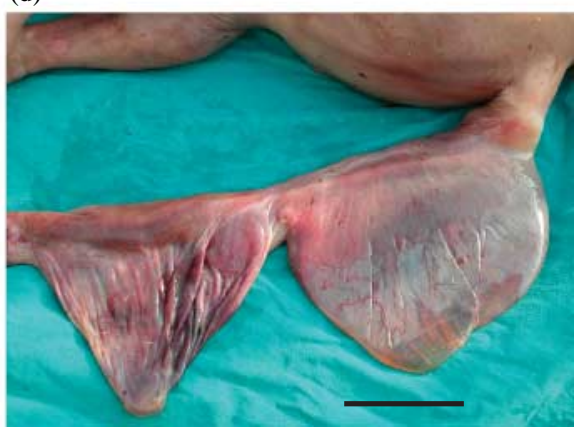

Figure 2 (a) Placenta of the fetus derived from an NT-horse blastocyst from fetal cells of male C; the arrow indicates the area without villi. (b) Umbilical cord of the same placenta with an allantoic fluid filled cystic structure $(\mathrm{bar}=10 \mathrm{~cm})$.

(c) Fetus of the placenta in (a) aborted at 180 days of gestation (bar $=20 \mathrm{~cm}$ ). (d) Umbilical cord of the fetus derived from an NT-horse blastocyst from an adult fibroblast of male $\mathrm{C}$ aborted at 231 days of gestation showing the same type of abnormality (bar $=10 \mathrm{~cm}$ ).

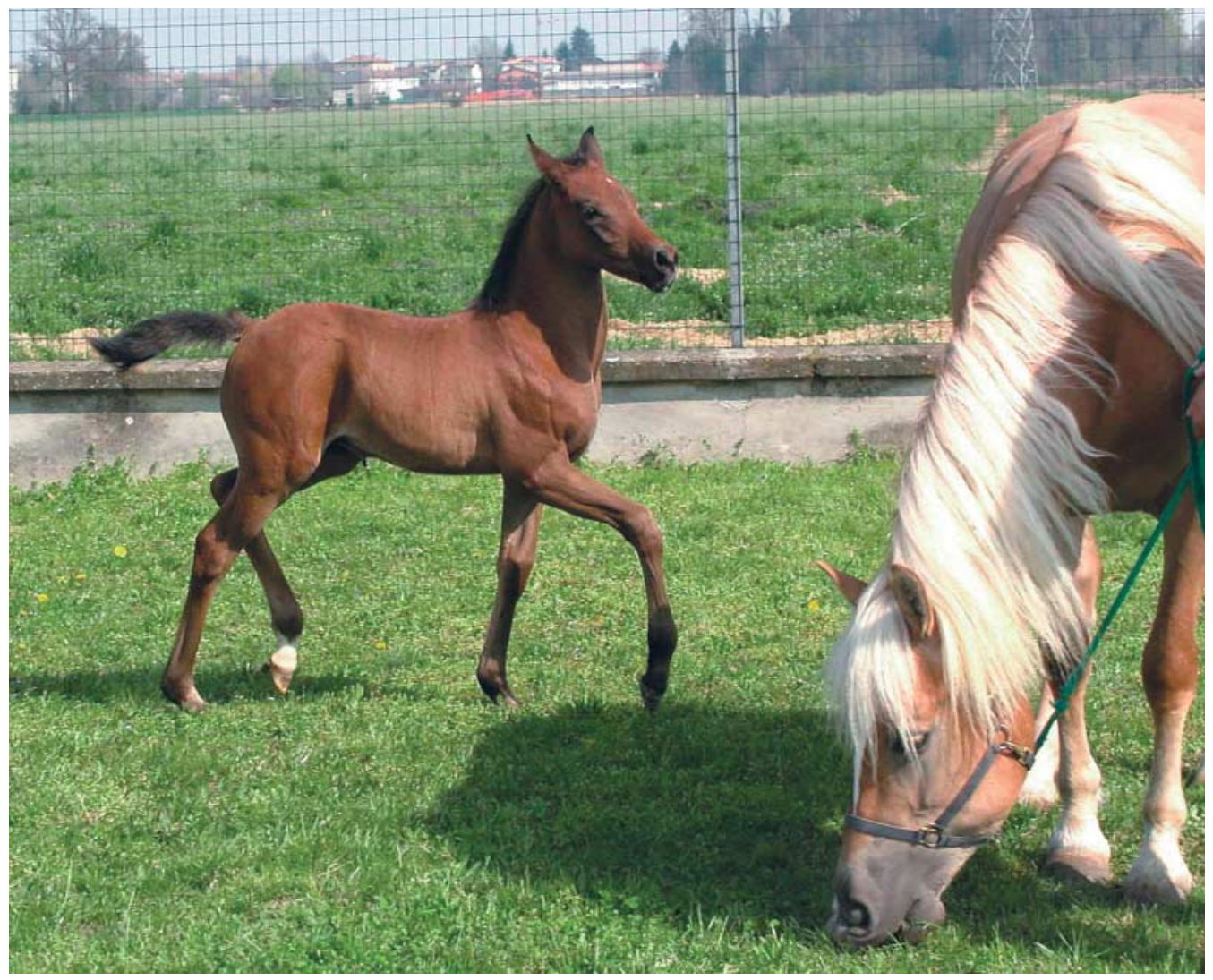

Figure 3 The foal derived from an NT-horse blastocyst from an adult cell of male B next to his Haflinger surrogate mother. 
zona-enclosed embryos as reported by Choi et al. (2003). For in vivo matured oocytes manipulated within the zona, Woods et al. (2003) reported that $90 \%$ fusion could be achieved after successive $2.25 \mathrm{kV} / \mathrm{cm}$ DC pulses until fusion occurred or the oocyte lyzed. In our experience, bovine couplets subjected to more than two successive DC pulses to achieve fusion have low developmental competence. In our study, we also observed an associated increase in the cleavage rate that was reflected in an increased development to the blastocyst stage.

In our experience in the horse, contrary to other species, expanded cumulus-oocyte complexes maintain some developmental competence after in vitro fertilization by ICSI, although oocytes with a compacted cumulus give rise to more embryos (Galli et al. 2000). However, the classification between compacted and expanded cumulus is not well defined in the literature and therefore the selection can be influenced by subjective criteria applied by different people. This may explain why, in another study, no difference in development was observed between compact and expanded oocyte-cumulus complexes (Tremoleda et al. 2003). In nuclear transfer embryos, as shown in this study, no differences were observed between the two types of cumulus-oocyte complexes and therefore the only reason to grade oocytes before maturation is the fact that expanded oocytes mature $2-4 \mathrm{~h}$ earlier than compact oocytes so they can be manipulated earlier.

Amongst the several types of cells tested in the zonafree method (cumulus cells, adult and fetal fibroblasts) there were no observed differences in the cleavage rate nor were there observed differences with parthenogenetic activation in contrast to what has been reported by others (Choi et al. 2003, Li et al. 2003). Subsequent embryo development to the blastocyst stage was, however, much lower ranging from 0 to $16 \%$ on average.

As in mice (Wakayama \& Yanagimachi 2001), pigs (Kühholzer et al. 2001, Yin et al. 2002, Lee et al. 2003) and cattle (Kato et al. 2000, Servely et al. 2003) we have found a significant difference in the developmental potential of NT-embryos derived from different cell cultures. Blastocyst formation rates with some donors were low and comparable to those found by Li et al. (2002). However, with one adult and one fetal cell line the development to the blastocyst stage was comparable to the parthenogenetic controls (15.8 and $16 \%$ vs $13 \%$ respectively) and comparable with in vivo data on development of cloned mule blastocysts on Day 14 (12\%; Woods et al. 2003). These data indicate that the source of the donor nuclei for nuclear transfer is a major source of variability in Equids as in other species.

Interestingly, the only fetus derived from fetal fibroblasts was aborted at the same time as the fetus derived from the genetically identical adult fibroblasts and had the same type of abnormality on the umbilical cord (see Fig. 2). The number of transfers with cumulus cell-derived embryos was small in this study and did not result in any pregnan- cies. However, we believe that this cell type can successfully serve as a nuclear donor in horse cloning as in cattle (Wells et al. 1998, Kato et al. 2000), mice (Wakayama \& Yanagimachi 2001), rabbits (Chesne et al. 2002), goats (Keefer et al. 2002) and in mules where NT-embryos derived from cumulus cells were able to implant in recipient mares and to survive to Day 80 of pregnancy (Vanderwall et al. 2004).

Pregnancy losses reported here are typical of cloned pregnancies in other species (Heyman et al. 2002, Chavatte Palmer et al. 2004) as well as those reported by Woods et al. (2003) with cloned mule embryos. Fifty-seven percent (4/7) of NT-pregnancies from adult fibroblasts were lost between Days 17 and 35, in comparison with less than $15 \%$ of early embryonic death in normal breeding (Villahoz et al. 1985, Ball 1993). Two pregnancies resulted in the natural birth of two male foals. The average development to term was $5.4 \%$ and depended on donor cell culture as in other cloned animals (see Wilmut et al. 2002 for a review).

The first ever cloned foal (Galli et al. 2003b) that was born from a Haflinger female adult fibroblast NT-embryo is now about 20 months old. Incidentally, she was born to the recipient that served as the nuclear donor for the nuclear transfer experiment and therefore she is the genetic copy of the surrogate mother. Interestingly, the outcome of this experiment is contrary to the idea that the maintenance of gestation depends on adequate immunological recognition of fetal antigens by the mother (Szekeres-Bartho 2002).

The number of observations made on advanced pregnancies that aborted is limited; however, the pattern is similar to that of other species whereby abnormalities have a higher incidence in the extraembryonic tissues. In our case, the umbilical cord was abnormal, which was the same observation reported by us for a previous abortion (Galli et al. 2003b). One placenta had an area without villi, which is compatible with normal pregnancies; appearance and thickness were normal. Also the placentae of the pregnancies that went to term were normal and the weight was in the normal range (LeBlanc 1997). The foal that died perinatally developed septicemia. This pathological situation is described in horse neonatology and can be a cause of death for the foal. It is difficult to correlate this event to the fact that it was a cloned offspring; however, it is known that perinatal mortality of cloned offspring in other species is higher than normal (Chavatte-Palmer et al. 2002, Cibelli et al. 2002).

In conclusion, we have investigated the developmental capacity of NT-embryos derived from cumulus cells and from adult and fetal fibroblasts to develop in vitro and of embryo and fetal development in vivo following embryo transfer into recipients. We have shown that different cell cultures possess different capacities for supporting the preimplantation development of horse NT-embryos and that blastocyst formation rate does not correlate with or predict future pregnancy fate. The zona-free method for embryo 
reconstruction proved very efficient in increasing the fusion rate and the efficient use of oocytes. In this study, oocytes with expanded and compact cumulus had equal ability to support the preimplantation development of NTembryos. Finally, horse embryos cloned from adult fibroblasts were able to implant and develop to term.

\section{Acknowledgements}

The technical support of Jordi Tremoleda and Massimo Iazzi is gratefully acknowledged. The clinical assistance for fetal monitoring and neonatal care of Gaetano Mari, Carolina Castagnetti and lole Mariella of the Dipartimento Clinico Veterinario, Università di Bologna and of Giovanni Zavaglia is also acknowledged. Critical reading of the manuscript and support during the course of this work by Eric Palmer and Pascale Chavatte-Palmer is acknowledged. The somatic cells of male origin were supplied by Eric Palmer (Cryozootech, France). This work was supported by FIRB (project n RBNE01HPMX), MIUR and Fondazione Cariplo. The authors declare that there is no conflict of interest that would prejudice the impartiality of this scientific work.

\section{References}

Ball BA 1993 Embryonic death in mares. In Equine Reproduction, pp 517-531. Eds AO McKinnon \& JL Voss. Media: Williams \& Wilkins.

Bogh IB, Bezard J, Duchamp G, Baltsen M, Gerard N, Daels P \& Greve T 2002 Pure preovulatory follicular fluid promotes in vitro maturation of in vivo aspirated equine oocytes. Theriogenology $\mathbf{5 7}$ 1765-1779.

Booth PJ, Tan SJ, Reipurth R, Holm P \& Callesen H 2001 Simplification of bovine somatic cell nuclear transfer by application of a zona-free manipulation technique. Cloning Stem Cells 3 139-150.

Carneiro G, Lorenzo P, Pimentel C, Pegoraro L, Bertolini M, Ball B, Anderson G \& Liu I 2001 Influence of insulin-like growth factor-I and its interaction with gonadotropins, estradiol, and fetal calf serum on in vitro maturation and parthenogenic development in equine oocytes. Biology of Reproduction 65 899-905.

Chavatte-Palmer P, Heyman Y, Richard C, Monget P, LeBourhis D, Kann G, Chilliard Y, Vignon X \& Renard JP 2002 Clinical, hormonal, and hematologic characteristics of bovine calves derived from nuclei from somatic cells. Biology of Reproduction 66 1596-1603.

Chavatte-Palmer P, Remy D, Cordonnier N, Richard C, Issenman H, Laigre P, Heyman Y \& Mialot JP 2004 Health status of cloned cattle at different ages. Cloning Stem Cells 6 94-100.

Chesne P, Adenot PG, Viglietta C, Baratte M, Boulanger L \& Renard JP 2002 Cloned rabbits produced by nuclear transfer from adult somatic cells. Nature Biotechnology 20 366-369.

Choi YH, Shin T, Love CC, Johnson C, Varner DD, Westhusin ME \& Hinrichs K 2002 Effect of co-culture with theca interna on nuclear maturation of horse oocytes with low meiotic competence, and subsequent fusion and activation rates after nuclear transfer. Theriogenology 57 1005-1011.

Choi YH, Chung YG, Walker SC, Westhusin ME \& Hinrichs K 2003 In vitro development of equine nuclear transfer embryos: effects of oocyte maturation media and amino acid composition during embryo culture. Zygote 11 77-86.

Choi YH, Roasa LM, Love CC, Varner DD, Brinsko SP \& Hinrichs K 2004 Blastocyst formation rates in in vivo and in vitro-matured equine oocytes fertilized by intracytoplasmic sperm injection. Biology of Reproduction 70 1231-1238.

Cibelli JB, Campbell KH, Seidel GE, West MD \& Lanza RP 2002 The health profile of cloned animals. Nature Biotechnology 20 13-14.
Dell'Aquila ME, Masterson M, Maritato F \& Hinrichs K 2001 Influence of oocyte collection technique on initial chromatin configuration, meiotic competence, and male pronucleus formation after intracytoplasmic sperm injection (ICSI) of equine oocytes. Molecular Reproduction and Development 60 79-88.

Dell'Aquila ME, Albrizio M, Maritato F, Minoia P \& Hinrichs K 2003 Meiotic competence of equine oocytes and pronucleus formation after intracytoplasmic sperm injection (ICSI) as related to granulosa cell apoptosis. Biology of Reproduction 68 2065-2072.

Galli C \& Lazzari G 2001 In vitro and in vivo culture in the sheep oviduct of equine embryos obtained by IVM and ICSI. In 2nd Meeting of the European Equine Gamete Group, Abstract, pp 55-56. Eds TAE Stout J F Wade. Newmartet: R \& W Publications.

Galli C, Crotti G, Duchi R, Mari G \& Lazzari G 2000 Embryonic development of equine oocytes fertilised by ICSI. Havemeyer Foundation Monograph Series n3, pp 32-34. 5th International Symposium on Equine Embryo Transfer, 6-9 July 2000. Eds T Katila \& JF Wade. Finland: Saari Unit of Helsinki University.

Galli C, Barbacini S, Crotti G, Turini P, Duchi R, Mari G, Belluzzi S, Marchi V \& Lazzari G 2001a Pregnancies obtained from equine embryos produced in vitro by ICSI. In 7th World Congress of World Equine Veterinary Association, Sorrento, Abstract, pp 319. Eds Weva \& Sive. Abbiategrasso: Press Point.

Galli C, Crotti G, Notari C, Turini P, Duchi R \& Lazzari G $2001 b$ Embryo production by ovum pick up from live donors. Theriogenology 55 1341-1357.

Galli C, Maclellan LJ, Crotti G, Turini P, Ponderato N, Duchi R, Merlo B, Mari G, Barbacini S \& Lazzari G 2002a Development of equine oocytes matured in vitro in different media and fertilised by ICSI. Theriogenology $\mathbf{5 7} 718$.

Galli C, Crotti G, Turini P, Duchi R, Mari G, Zavaglia G, Duchamp G, Daels P \& Lazzari G 2002b Frozen-thawed embryos produced by ovum pick up of immature oocytes and ICSI are capable to establish pregnancies in the horse. Theriogenology $\mathbf{5 8}$ 705-708.

Galli C, Lagutina I \& Lazzari G 2003a Introduction to cloning by nuclear transplantation. Cloning Stem Cells 5 223-232.

Galli C, Lagutina I, Crotti G, Colleoni S, Turini P, Ponderato N, Duchi R \& Lazzari G 2003b Pregnancy: a cloned horse born to its dam twin. Nature $\mathbf{4 2 4} 635$.

Gardner DK, Lane M, Spitzer A \& Batt P 1994 Enhanced rates of cleavage and development for sheep zygotes cultured to the blastocyst stage in vitro in the absence of serum and somatic cells: amino acids, vitamins and culturing embryos in groups stimulate development. Biology of Reproduction 50 390-400.

Heyman Y, Chavatte-Palmer P, LeBourhis D, Camous S, Vignon X \& Renard JP 2002 Frequency and occurrence of late-gestation losses from cattle cloned embryos. Biology of Reproduction 66 6-13.

Hinrichs K \& Williams K 1997 Relationships among oocyte-cumulus morphology, follicular atresia, initial chromatin configuration and oocyte meiotic competence in the horse. Biology of Reproduction $57377-384$

Kato Y, Tani T \& Tsunoda Y 2000 Cloning of calves from various somatic cell types of male and female adult, newborn and fetal cows. Journal of Reproduction and Fertility $\mathbf{1 2 0} 231-237$.

Keefer CL, Keyston R, Lazaris A, Bhatia B, Begin I, Bilodeau AS, Zhou FJ, Kafidi N, Wang B, Baldassarre H \& Karatzas CN 2002 Production of cloned goats after nuclear transfer using adult somatic cells. Biology of Reproduction 66 199-203.

Kühholzer B, Hawley RJ, Lai L, Kolber-Simonds D \& Prather RS 2001 Clonal lines of transgenic fibroblast cells derived from the same fetus result in different development when used for nuclear transfer in pigs. Biology of Reproduction 64 1695-1698.

Lazzari G, Crotti G, Turini P, Duchi R, Mari G, Zavaglia G, Barbacini S \& Galli C 2002a Equine embryos at the compacted morula and blastocyst stage can be obtained by intracytoplasmic sperm injection (ICSI) of in vitro matured oocytes with frozenthawed spermatozoa from semen of different fertilities. Theriogenology 58 709-712. 
Lazzari G, Mari G \& Galli C 2002b Synergistic effect of cycloheximide and 6-DMAP on activation of equine and bovine oocytes. Journal of Reproduction and Fertility Abstract Series No 2873.

LeBlanc MM 1997 Immediate care of the postpartum mare and foal. In Current Therapy in Large Animal Theriogenology, pp 157-160. Ed. RS Youngquist. Philadelphia: WB Saunders Company.

Lee G, Hyun S, Kim H, Kim D, Lee S, Lim J, Lee E, Kang S, Lee B \& Hwang W 2003 Improvement of a porcine somatic cell nuclear transfer technique by optimizing donor cell and recipient oocyte preparation. Theriogenology 59 1949-1957.

Li X, Morris LHA \& Allen WR 2002 In vitro development of horse oocytes reconstructed with the nuclei of fetal and adult cells. Biology of Reproduction 66 1288-1292.

Li X, Tremoleda JL \& Allen WR 2003 Effect of the number of passages of fetal and adult fibroblasts on nuclear remodelling and first embryonic division in reconstructed horse oocytes after nuclear transfer. Reproduction 125 535-542.

Lorenzo PL, Liu IK, Carneiro GF, Conley AJ \& Enders AC 2002 Equine oocyte maturation with epidermal growth factor. Equine Veterinary Journal 34 378-382.

Oback B, Wiersema AT, Gaynor P, Laible G, Tucker FC, Oliver JE, Miller AL, Troskie HE, Wilson KL, Forsyth JT, Berg MC, Cockrem K, McMillan V, Tervit HR \& Wells DN 2003 Cloned cattle derived from a novel zona-free embryo reconstruction system. Cloning Stem Cells 5 3-12.

Servely JL, Le Bourhis D, Freret S, Laloy E, Heyman Y, Renard JP \& Vignon X 2003 Comparison of developmental potential of keratinocytes and fibroblasts after nuclear transfer in bovine. Theriogenology 59288 (Abstract).

Squires EL, Carnevale EM, McCue PM \& Bruemmer JE 2003 Embryo technologies in the horse. Theriogenology 59 151-170.

Szekeres-Bartho J 2002 Immunological relationship between the mother and the fetus. International Reviews in Immunology $\mathbf{2 1}$ 471-495.

Tremoleda JL, Stout TA, Lagutina I, Lazzari G, Bevers MM, Colenbrander B \& Galli C 2003 Effects of in vitro production on horse embryo morphology, cytoskeletal characteristics and blastocyst capsule formation. Biology of Reproduction 69 1895-1906.

Vajta G, Lewis IM, Hyttel P, Thouas GA \& Trounson AO 2001 Somatic cell cloning without micromanipulators. Cloning Stem Cells 3 89-95.
Vajta G, Lewis IM, Trounson AO, Purup S, Maddox-Hyttel P, Schmidt M, Pedersen HG, Greve T \& Callesen H 2003 Hand made somatic cell cloning in cattle: analysis of factors contributing to high efficiency in vitro. Biology of Reproduction 68 571-578.

Vanderwall DK, Woods GL, Aston KI, Bunch TD, Li GP, Meerdo LN \& Woods GL 2004 Cloned horse pregnancies produced using adult cumulus cells. Reproduction and Fertility Development $\mathbf{1 6}$ 160 (Abstract no. 76)

Villahoz MD, Squires EL, Voss JL \& Shideler RK 1985 Some observations on early embryonic death in mares. Theriogenology 23 915-924.

Wakayama T \& Yanagimachi R 2001 Mouse cloning with nucleus donor cells of different age and type. Molecular Reproduction and Development 58 376-383.

Wells DN, Misica PM, Tervit HR \& Vivanco WH 1998 Adult somatic cell nuclear transfer is used to preserve the last surviving cow of the Enderby Island cattle breed. Reproduction and Fertility Development 10 369-378.

Westhusin M, Hinrichs K, Choi Y-H, Shin T, Liu L \& Kraemer D 2003 Cloning companion animals (horses, cats, and dogs). Cloning and Stem Cells 5 301-317.

Wilmut I, Beaujean N, de Sousa PA, Dinnyes A, King TJ, Paterson LA, Wells DN \& Young LE 2002 Somatic cell nuclear transfer. Nature 419 583-586.

Woods GL, White KL, Vanderwall DK, Li GP, Aston KI, Bunch TD, Meerdo LN \& Pate BJ 2003 A mule cloned from fetal cells by nuclear transfer. Science 3011063.

Yin XJ, Tani T, Yonemura I, Kawakami M, Miyamoto K, Hasegawa R, Kato Y \& Tsunoda Y 2002 Production of cloned pigs from adult somatic cells by chemically assisted removal of maternal chromosomes. Biology of Reproduction 67 442-446.

Zhang J, Boyle MS, Allen WR \& Galli C 1989 Recent studies on in vivo fertilization of in vitro matured horse oocytes. Equine Veterinary Journal 8 Suppl 101-104.

Received 27 April 2005

First decision 2 May 2005

Accepted 30 June 2005 